Article

\title{
Adoption and Use of Low-Carbon Technologies: Lessons from 100 Finnish Pilot Studies, Field Experiments and Demonstrations
}

\author{
Eva Heiskanen ${ }^{1, *}$, Kaarina Hyvönen ${ }^{1}$, Senja Laakso ${ }^{1}$, Päivi Laitila ${ }^{2}$, Kaisa Matschoss ${ }^{1}$ \\ and Irmeli Mikkonen ${ }^{2}$ \\ 1 Consumer Society Research Centre, Department of Political and Economic Studies, \\ University of Helsinki, 00014 Helsinki, Finland; kaarina.hyvonen@helsinki.fi (K.H.); \\ senja.laakso@helsinki.fi (S.L.); kaisa.matschoss@helsinki.fi (K.M.) \\ 2 Motiva Ltd., 00100 Helsinki, Finland; paivi.laitila@motiva.fi (P.L.); irmeli.mikkonen@motiva.fi (I.M.) \\ * Correspondence: eva.heiskanen@helsinki.fi; Tel.: +358-50-3210190
}

Academic Editor: Yongrok Choi

Received: 7 April 2017; Accepted: 10 May 2017; Published: 18 May 2017

\begin{abstract}
Experimentation is critical for the deployment of low-carbon technologies. New solutions need to be selected and adapted to their contexts of use, and users need to learn new skills. Society as a whole needs to create new modes of production, consumption and governance. We investigated how local pilot projects, demonstrations and trials of low-carbon technologies promote learning in Finnish society, where the government has made a commitment to a culture of experimentation. We drew on a database of 100 pilot projects and experiments and 15 detailed case studies. We identified several types of learning, beyond the formal evaluation of "what works where and when": pilot projects served to inspire, to create commitment and to develop networks. We also investigated how lessons learned are transferred to other sites and into societal knowledge. We contribute by conceptualizing different forms of learning and transfer-particularly situated and embodied forms-alongside more techno-scientific ones. While highlighting this form of learning, we also note that it is not particularly strong in acknowledging challenges faced in experimentation. We argue that there is scope for more systematic evaluation, alongside more situated forms of learning and sharing. We also pinpoint tensions between these two forms of learning that need to be addressed.
\end{abstract}

Keywords: low-carbon technologies; pilot projects; demonstrations; experiments; learning

\section{Introduction}

Ambitious climate targets will require the widespread adoption of cleaner energy sources and more efficient energy use patterns and solutions. Before adoption on a large scale, however, low-carbon solutions need to be tested and experimented [1-4]. Decision makers need to discover how technologies work in real life conditions. Users and technology developers need to anticipate cost-effectiveness and reliability. However, other kinds of lessons might also be drawn from demonstrations and pilot projects. We can see what skills are needed to deploy the new technologies, what supportive systems are lacking, what problems users encounter when using them, and what unanticipated consequences new technologies may have [4]. However, it is still unclear what kinds of learning occur across a wide range of low-carbon pilot projects and demonstrations at a given time, how purposively and relevantly lessons learned are transferred across individual sites, and how pilot projects contribute to learning in society at large.

Local learning through small-scale experimentation plays a recognized role in the process through which new technologies are mainstreamed. For example, the current European demands for nearly 
zero-energy buildings would not likely be possible without the early experimentation which has occurred since the 1980s-1990s with passive houses, for example by the Passive House Institute [5]. Similarly, several scholars have pointed to the important role of local learning, for example through the 1000 Roofs and 100,000 Roofs Programmes, in the development of the legitimacy and necessary technological capabilities for the German solar power rollout [6,7].

The notion of strategic experimentation for low-carbon transitions takes a more purposive and society-wide approach to learning [8]. This line of thought builds, on the one hand, on the research tradition of strategic niche management (SNM), where experiments in protected local niches serve as means for variation, selection and retention in the evolutionary development trajectories of new socio-technical innovations [1,9]. On the other hand, it draws on notions of experimental governance and the idea of devolving the search for solutions to policy problems to local actors [10]. This line of thought has gained traction in recent years among policy makers searching for radical renewal of governance processes and acceleration of innovative capacity [11]. Among such governments is the 2015 Cabinet of Finland, with a government programme which pledges to introduce a culture of experimentation [12].

Our paper focuses on the role of experimentation by users of new low-carbon technologies and related organizational solutions. Experimentation here refers to the acquisition of early experience in field trials, pilot projects, demonstrations and experiments (in the following, referred to interchangeably as pilot projects or local experiments). By low-carbon technologies and solutions, we refer to combinations of technical and/or organizational means for the deployment and management of low-energy solutions and renewable, intermittent energy in the built environment and transport. By users, we refer to companies, public sector or non-profit organizations, and households involved in the deployment of new technologies. By deployment, we refer to processes of combining and adapting technologies, integrating them into existing structures, as well as processes of giving these technologies meaning $[13,14]$.

We investigate the role of pilot projects, demonstrations and publicly funded trials of low-carbon solutions in learning and in the identification of potential "points of friction" between new technologies, their intended users and wider society. Our research questions are:

(1) What types of learning can be identified in these low-carbon technology trials?

(2) To what extent are lessons about adoption, adaptation and use shared between individual pilots and demonstrations or aggregated across several pilots and demonstrations?

(3) To what extent are experiences and lessons learned about difficulties in adoption, adaptation and use documented, analysed, evaluated and used for improvements?

In the following section, we conceptualize the types of learning related to these highly diverse goals and aims of local low-carbon experimentation. We then present our data and methods. Subsequently, we investigate, illustrate and elaborate on different types of learning observed in contemporary Finnish experimentation with cleaner energy sources and more energy efficient solutions. Given that local experimentation can give rise to very different types of learning, we also explore different ways in which such lessons are rendered mobile and useful for a broader group of users beyond the immediate circle of participants. Our results also consider the types of lessons to be derived concerning necessary and missing competences when deploying low-carbon technologies. Our contribution is to develop an empirically and theoretically grounded framework of two major categories of learning observed in the field, as well as to identify potential tensions between these two categories that need to be resolved if both types of learning are to be promoted.

\section{Conceptual Approaches to Learning in Pilot Projects and Demonstrations}

Pilot projects, demonstrations, field trials and local experimentation with new technologies have been said to serve several purposes. Drawing on Schot and Geels [1], Fevolden et al. [4], Berg et al. [8], 
Heiskanen et al. [3], Rose [15], Lovell [16], and Chini et al. [17], the following aims and purposes can be identified:

- $\quad$ testing the technical, market and environmental feasibility of new solutions

- the development of feedback and technocratic knowledge of "what works where and why"

- the development of users' and producers' skills and capacities in using new technologies

- the development of new networks and communities supporting the new solutions

- reflective learning on what is desirable and acceptable

- the communication and promotion of particular solutions via "real-life stories"

- the inspiration of participants and policy makers

- the challenging of existing structures and practices

- the development of improved and more sustainable living environments and infrastructures for participants

Correspondingly, there is no dominant theory of learning that covers all relevant learning processes in local experimentation with low-carbon applications [4]. Two lines of research are particularly pertinent to our research problem. The first line of research, that on strategic experimentation, investigates the role of experiments in broader processes of social learning for societal transitions, and it highlights the role of learning as the development of new cognitive rules and the aggregation of lessons learned $[9,18]$. The second line of research highlights the importance of tacit knowledge obtained through learning by using, doing and interacting, and has recently been applied in particular to the deployment of distributed energy technologies $[4,14]$. This aspect of learning has not been conceptualized very clearly in the otherwise vibrant literature on learning from experimentation [19-21].

The perspective of strategic niche management highlights the learning that occurs in local niches when new technologies are experimentally deployed in real-life settings [1]. Learning relates to the development of technical solutions and capabilities, but also to the explorative development and joint knowledge creation in relevant supply chains and value networks [3]. Learning is also needed to adapt new technologies to existing regulations and infrastructures and to explore the societal and environmental impacts of new technical solutions. New technologies also need to be adapted to markets and user needs, and local niches offer opportunities for technology proponents to learn about users and early markets [1]. Finally, in order to find a place in society, cultural meaning and identity need to develop around new technologies, and niches offer a place for this kind of learning as well [12].

The notion of strategic experimentation has also been applied to the governance of low-carbon technologies [11]. This perspective encapsulates the view of those undertaking local experimentation, including non-scientists, as a new form of societal knowledge production, emphasizing a feedback cycle of development, testing, evaluation and informing best practice management [16], or foresight, experimentation and learning in the management of societal transitions [22,23]. Experiments in this line of thought support learning about the possibilities and problems of new governance structures, or new technologies from a governance perspective. The main aim of such experimentation is thus to obtain information: an experiment is a failure only if it does not provide new information for broader societal decision-making processes [24].

While recognizing the socio-political aspects of experimentation, the strategic experimentation literature foregrounds the techno-scientific and cognitive dimensions of learning, for example highlighting the need for aggregation of lessons learned in local experiments in order to support the emerging niche trajectories $[9,17]$. In contrast, the perspective of learning by doing, using and interacting (DUI) highlights the importance of tacit, embodied and local knowledge and skills developed in interaction [4,25]. It draws on notions of learning elaborated on within situated learning theory [26], which perceives of learning as emergent, involving opportunities to participate in the practices of the community as well as the development of an identity which provides a sense of belonging and commitment [27]. 
From this perspective, learning can also entail the development of participants' tacit and embodied skills and confidence through participation, even if cognitive lessons remain unarticulated. Participation in a pilot can also entail "experimentation with potential selves" [28], i.e., the development of new identities and the reshaping of roles and professional profiles. In a similar vein, both the DUI and situated learning perspectives highlight the importance of interaction [25] and networks of practice [29]. Learning can thus pertain to the development of commitment and shared language and practice within new networks, such as supply chains, value chains or communities of interest or practice. In addition to formal aggregation, learning can also accrue locally via knowledge spillovers: face-to-face transfer of tacit knowledge, buzz (i.e., spread of awareness via ad hoc discussions) and pooled resources (e.g., shared contractors) [13,30]. This type of learning can pertain to embodied skills or the coordination of work, but it can also pertain to a reshaping of personal and professional orientations and valuations [31].

As a further point that stresses other than cognitive aspects of learning, Berg et al. [8] suggest that field experiments can serve to disrupt existing practice by creating a temporary space where new and different (rather than conventional) rules apply. This aspect of learning has been elaborated by Polley and van de Ven [32] when discussing the types of discovery-oriented learning processes that precede learning by trial-and-error. This type of learning as trail-blazing [32] refers to processes where new paths are created, and sometimes displayed in dramatic ways in order to change judgement criteria, i.e., introduce new values and feelings about the technology [33]. This category of learning corresponds roughly to notions of demonstrations as "exemplification", but also recognizes that such exemplification can relate to broader institutional embedding of new solutions for societal change [4].

While the two streams of literature introduced above engage with similar topics, such as the development of networks, they highlight different dimensions of learning. Table 1 summarizes the conceptual framework we used to investigate learning in our case studies. Column 1 summarizes the more cognitive and techno-scientific aspects of learning foregrounded by the strategic experimentation literature, while column 2 summarizes types of learning highlighted when focusing on the situated, tacit and affective dimensions.

Table 1. Conceptual categorization of types of learning.

\begin{tabular}{ll}
\hline Techno-Scientific, Cognitive Learning & Situated Learning: New Identities and Practices \\
\hline Testing functionality and market demand & Enhancing skills and confidence-new identities \\
Improving solutions in context & Reshaping roles and professional profiles \\
Transfer to other sites, systematic improvement & Building new networks and communities \\
New form of societal knowledge production: What & Inspiration and trailblazing \\
works where, when, how and why (or why not)? & \\
\hline
\end{tabular}

\section{Materials and Methods}

We draw on a database of 100 Finnish demonstrations, pilot projects and field trials. We have focused on four types of pilot project that are today visible in Finnish society and to which significant public funding has also been devoted: (1) regional or urban pilot projects combining several kinds of low-carbon technologies and practices, e.g., low-energy buildings, renewable energy, progressive spatial planning and new services for residents in entire residential or industrial districts; (2) demonstration buildings or installations: in these, new technologies such as nearly-zero energy construction and heating, ventilation and air conditioning solutions are combined with technologies like e.g., solar power and heat pumps in (new or renovated) residential or office buildings with different forms of tenure; (3) experimentation with new business models (e.g., energy services) or new organizational models for the purchasing, management or use of low-carbon technologies, such as joint procurement of solar panels, crowdsourcing or crowdfunding; as well as (4) experimentation with new transport systems, e.g., electric vehicles and their charging solutions, often combined with novel service solutions such as mobility as a service. 
The database was collected on the basis of an internet search and a press release inviting relevant pilots to get in touch. Moreover, we have used snowballing, asking our interviewees to identify other relevant field experiments and pilot projects. The full list of cases in the database is presented in Appendix A.

We zoom in to our research questions through 15 more detailed case studies (Table 2). The cases were selected to include each category of pilot projects, with an emphasis on the diverse and complex urban pilot projects, since they often include several aspects of the other categories as well (buildings and installations, new business models, new organization models, transport pilots). Moreover, attempts were made to select cases that were ambitious and involved a diversity of actors, as well as cases from different parts of the country. A list of the case reports used as material for the present article is presented in Appendix B.

Table 2. Case studies selected for closer analysis.

\begin{tabular}{|c|c|}
\hline 1. Regional/Urban Pilot Projects & Summary of Context and Focus \\
\hline Smart Kalasatama, Helsinki & $\begin{array}{l}\text { New build urban living lab area in central Helsinki experimenting with smart city solutions, } \\
\text { including smart controls, solar, storage and digital applications. Intensive co-creation and rapid } \\
\text { prototyping of energy and transport solutions with start-ups, established companies and users. }\end{array}$ \\
\hline Climate Street, Helsinki & $\begin{array}{l}\text { Promoting renewable energy and sustainable lifestyles and business in existing built } \\
\text { environments using rapid prototyping of energy and transport solutions. }\end{array}$ \\
\hline $\begin{array}{l}\text { Public procurement for smart energy, } \\
\text { Lappeenranta }\end{array}$ & $\begin{array}{l}\text { Municipal efforts to use public purchasing (municipally-owned vehicles) as a leverage to promote } \\
\text { a local smart energy ecosystem, including a pilot power-to-gas facility. }\end{array}$ \\
\hline HINKU carbon-neutral municipalities & $\begin{array}{l}\text { Programme in which municipalities commit to reduce greenhouse gas emissions by } 80 \% \text { by } 2030 \text {, } \\
\text { receiving tailored support from coordinators at the Finnish Environment Institute. Measures focus } \\
\text { mainly on existing built environment (energy efficiency, renewable energy sources). }\end{array}$ \\
\hline Viikki Environment House & $\begin{array}{l}\text { Low-energy office building with solar and wind power, ground-source cooling and advanced } \\
\text { automation, smart EV charging and battery power storage. }\end{array}$ \\
\hline Mestariasunnot care facility, Järvenpää & $\begin{array}{l}\text { Low-energy building (municipal care facility) with solar heat and power, including heat supplied } \\
\text { for neighbouring buildings. }\end{array}$ \\
\hline \multicolumn{2}{|l|}{ 3. New Business and Organization Models } \\
\hline Joint purchasing of solar panels & $\begin{array}{l}\text { Series of a total of } 14 \text { joint purchases of solar panels organized at different sites, for households, } \\
\text { farmers and municipalities, aiming to reduce the cost and inconvenience of obtaining solar panels } \\
\text { by customers joining forces. }\end{array}$ \\
\hline Farm Power Service by Oulun Energia & Service to sell distributed renewable power directly from small producers to customers. \\
\hline St1 Deep Heat & $\begin{array}{l}\text { Pilots project to drill deep geothermal well up to } 7 \mathrm{~km} \text { in order to supply } 120^{\circ} \mathrm{C} \text { hot water to an } \\
\text { existing district heating network. }\end{array}$ \\
\hline
\end{tabular}

The case studies are based on at least three interviews with the main pilot manager and key participants, but in most cases, on extensive interview data (up to 24 interviews) with funding bodies, residents, local politicians and civil servants. Interviews were based on an interview guide focusing on the aims of the pilot and perceptions of success and failure and lessons learned in the pilot, as well as questions concerning documentation, evaluation and sharing of lessons. The interviews were complemented with extensive document material (project reports, feasibility studies and media coverage) as well as results from a compendium report by Motiva [34]. Additional data were collected in two workshops for national-level officials and experts in charge of experimentation with new energy solutions in Finland. 
Some of this work is still in progress: this paper outlines our preliminary findings and conceptualizes them through the lenses of the local learning and strategic experimentation literature. Through this, we aim to identify the types of learning visible in the cases as well as consider how the local experiments contribute to societal learning.

\section{Results}

\subsection{Overview of Learning Processes and Outcomes}

In the following, we outline and illustrate different types of learning observed in the pilot projects, starting with the more cognitive learning categories and then moving on to reflect on situated learning. Table 3 indicates the types of learning observed in each case.

Testing functionality, market demand and user acceptance is one of the most widely observed forms of learning among the case studies. It is one of the most obvious ways in which local experimentation can contribute to learning, offering a contemporary alternative to a linear and much slower model of product development [35] where solutions are refined before they are brought to the market. This is one of the most fundamental types of learning highlighted in the strategic niche management literature [1].

Beyond what can be found in previous case studies [1,20], we observed some interesting ways to accelerate such learning and support the rapid introduction of low-carbon solutions into real-life environments for testing and feedback. For example, the Smart Kalasatama living lab environment in central Helsinki has pioneered a programme for "agile piloting". This is a twice-yearly call for 3-5 concepts for more sustainable, digital solutions to be piloted for functionality and user feedback. Ideas can derive from user communities or start-ups, but they need to be mature enough to be tested within 6 months at a cost of $€ 1000-8000$ [36]. Examples of concepts tested include ride-sharing for goods, smart charging of electric vehicles with solar power, a service enabling housing associations to produce and share solar power, and the development of climate-smart practices and incentives for residents. As these climate-related experiments are currently being tested, it is impossible to tell their impacts as yet. Nevertheless, the concept of agile piloting initiated in Smart Kalasatama has spread within the city of Helsinki to another experimental location, Climate Street. A project, Resource Efficient Existing Buildings (Reeb), within the Programme for Agile Piloting in Climate Street tested the functionality of software that could estimate how many building users were in the building in real-time so that the owner could better follow up the energy consumption of the building and the degree of its utilization [37]. The pilot project produced important information for the improvement of the functionality of the software and it is further tested in other sites in Helsinki.

Improving solutions is another relatively obvious way to learn from pilot projects, and all our case studies involved some measures to improve initial designs. However, such improvement is critical when several smart energy technologies (even mature ones) are combined in a real-life environment.

One example of the effort required to improve technologies and make them work together even in one site is the Adjutantti smart pilot building [38], which has attempted to combine smart energy monitoring and control technologies in an advanced building automation system deployed in a new-built owner-occupied multifamily house, including solar power and electric vehicle (EV) charging, and initially also a shared EV. In this type of case, ownership and responsibility for the building is transferred to residents, represented by a residents' board. Since they are dealing with a combination of technologies, it often takes several months or even years to get building systems to work together with each other, and to find the right ways to manage and adapt the novel systems. For example, the residents' board, together with the companies Skanska and ABB who designed the building, made significant efforts to make the heating system automation work as planned. While the system has not been transferred as such to other sites, the learning processes in adjusting the system in real-life conditions were important for the companies involved for subsequent system redesign. 
Table 3. Types of learning observed in each case.

\begin{tabular}{|c|c|c|c|c|c|c|c|c|}
\hline \multirow[t]{2}{*}{ Types of Learning } & \multicolumn{4}{|c|}{ Techno-Scientific, Cognitive } & \multicolumn{4}{|c|}{ Situated } \\
\hline & $\begin{array}{l}\text { Testing Functionality } \\
\text { and Market Demand }\end{array}$ & $\begin{array}{l}\text { Improving Solutions } \\
\text { in Context }\end{array}$ & $\begin{array}{l}\text { Transfer and } \\
\text { Improvement }\end{array}$ & $\begin{array}{c}\text { Societal Knowledge } \\
\text { Production }\end{array}$ & $\begin{array}{l}\text { Enhancing Skills, } \\
\text { Confidence, Identity }\end{array}$ & Reshaping Roles & $\begin{array}{l}\text { New Networks and } \\
\text { Communities }\end{array}$ & $\begin{array}{l}\text { Inspiration and } \\
\text { Trailblazing }\end{array}$ \\
\hline Smart Kalasatama & 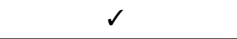 & $\checkmark$ & 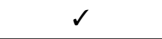 & $(\sqrt{ })$ & 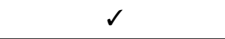 & $\checkmark$ & $\checkmark$ & $s$ \\
\hline Skaftkärr Porvoo & $\checkmark$ & 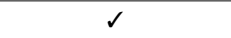 & $\checkmark$ & $(\boldsymbol{\checkmark})$ & 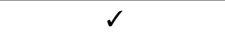 & 2 & & 2 \\
\hline Climate Street & $\checkmark$ & $\checkmark$ & & & 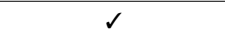 & $(\sqrt{ })$ & & $\checkmark$ \\
\hline $\mathrm{ECO} 2$ programme & 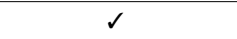 & $\checkmark$ & $\checkmark$ & $(\mathfrak{\checkmark})$ & 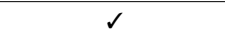 & $\checkmark$ & $\checkmark$ & 2 \\
\hline Public procurement for smart energy & 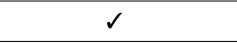 & $\checkmark$ & & & 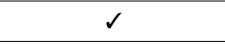 & & $\checkmark$ & $\checkmark$ \\
\hline HINKU carbon-neutral municipalities & 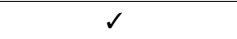 & $\checkmark$ & $\checkmark$ & & 2 & $\checkmark$ & $\checkmark$ & 2 \\
\hline Adjutantti smart low-energy house & $\checkmark$ & 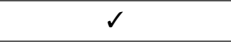 & & & $(\sqrt{ })$ & & & $\checkmark$ \\
\hline Viikki Environment House & $\checkmark$ & 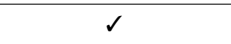 & $\checkmark$ & & 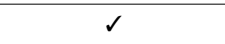 & & & $\checkmark$ \\
\hline Mestariasunnot care facility & 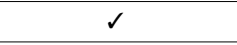 & $\sqrt{2}$ & 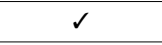 & & 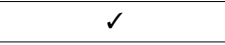 & & & $\checkmark$ \\
\hline Joint purchasing of solar panels & $\checkmark$ & 2 & 2 & $\checkmark$ & $\checkmark$ & $\checkmark$ & & 2 \\
\hline Farm Power service by Oulun Energia & $\checkmark$ & 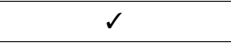 & & & 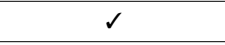 & $\checkmark$ & & $\checkmark$ \\
\hline St1 Deep Heat & $\checkmark$ & $\checkmark$ & & & $\checkmark$ & & & $\checkmark$ \\
\hline Crowdfunding for shared EVs & 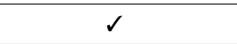 & $\checkmark$ & & & & 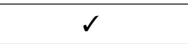 & 2 & $\checkmark$ \\
\hline Finnish electric mobility group pilots & 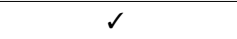 & 2 & $\checkmark$ & $(\boldsymbol{\checkmark})$ & $\checkmark$ & 2 & $\checkmark$ & 2 \\
\hline Jyväskylä Bus Leap & 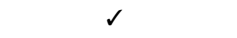 & $d$ & $(\sqrt{ })$ & & $\checkmark$ & $\checkmark$ & & $\checkmark$ \\
\hline
\end{tabular}

$\checkmark$ indicates that this type of learning was observed clearly; $(\checkmark)$ indicates the type of learning was implicit. 
Transfer to other sites, systematic improvement and scaling up is a more advanced form of learning, where lessons learned at one site are transferred to other sites, and potentially larger scales. We observed some form of this kind of learning in most cases, though improvement and scaling up were often sporadic. This is partly due to difficulties in funding subsequent pilot projects, often also because funding bodies may lose interest after a novel concept has been tested once. Some concepts might require more long-term support in order to develop into viable solutions. If the time-lag between pilot projects becomes too long, conditions may change so much that the solutions originally tested might not correspond to technically improved, new solutions available on the market. This was observed in many of the urban pilots, where the time-lag from zoning plans and feasibility studies to construction may take several years.

Solutions that require limited infrastructure appeared to be easier to transfer and scale up rapidly. One example of systematic transfer, improvement and scaling is the case of joint purchasing of solar panels. This is an initiative to bring together customers (consumers, farms, municipalities) to jointly invite and evaluate tenders for solar panel systems in order to reduce costs, gain information support and wield consumer power. Originally initiated by a private person, the Finnish Environment Institute took up the idea and has multiplied and scaled it up. These initiators, as well as several municipalities, have organised a total of 14 joint purchasing initiatives since 2012 [39,40]. Based on lessons learned from previous initiatives, these have grown in scale and level of professionalism, and most recently extended to other low-carbon technologies alongside solar panels.

Experimentation as societal knowledge production was a widely recognized aim and most of the cases received public funding in one form or another. However, only part of our case studies engaged in systematic documentation and evaluation, and even public funding bodies have quite variable expectations concerning how and what should be documented and evaluated. We did observe some systematic evaluations by or for individual cases: For example, the ECO2 project in Tampere has conducted several evaluations of different parts of the programme (some of them quite critical) and drawn some more general conclusions across the entire programme [41]. These evaluations have given rise to an identification of problems to be solved locally (for example, lack of skills and care in installing and combining new low-carbon solutions in buildings), but little of this information has percolated to national-level debates on competence needs [42].

Moreover, we found limited evaluation across the case studies or across projects of similar types, which would allow for investigating the relationship between solutions tested, contextual features and outcomes [20,43]. This is partly because some of the local experiments featured in our database are still ongoing. However, we did find one example of a funding body (The Housing Finance and Development Centre of Finland, Ara) contracting a cross-pilot evaluation of 16 low-energy housing pilots (including ones in our database) which rendered relevant observations and recommendations concerning the most promising and important lines of further development [44].

We next turn to consider forms of situated learning. This type of learning deals with the creation of new identities and practices rather than cognitive, explicit and techno-scientific forms of learning.

Enhancing skills and confidence and the creation of new identities is quite naturally present in all kinds of experimentation-given that it delivers some form of successful outcomes. While a failed experiment can be quite helpful for cognitive learning, it does not necessarily give participants confidence and enhance their identities as practitioners of low-carbon technologies. Conversely, cognitive learning can be quite scattered, but local experiments can still make a difference for participants' skills and confidence.

This was highlighted in the case of HINKU, a carbon-neutral municipalities' programme currently engaging 33 small and medium-sized municipalities. While there has been limited systematic testing of any particular technologies or concepts across these municipalities, and evaluation of the programme has focused on carbon reductions (with until now, limited analysis of why they occur), the programme has been extremely successful in enhancing the skills of local participants (municipalities, businesses and citizens). By producing small wins and inspiring success stories, it has 
also served to give participants confidence and enhance positive local identities. Interviews with local politicians highlighted the importance of these small wins_-before they became evident, commitment was limited [3].

Another example of the creation of local skills and identities in the Bus Leap experiment. Since the aim was to increase the share of public transport, the experiment served to raise the profile of public transportation in Jyväskylä, which has been a relatively car-dependent town. The local transport planners have adopted a new way of testing and experimenting with new services, such as free transport for people with baby prams, or complementing existing route-based public transport with personalized, on-demand services. Decisions about whether to start a new permanent service are made on the basis of experimentation and development, rather than assumptions. Local planners thus gained new skills and ways of working.

Skills and confidence were also developed in the case of the Finnish Electric Mobility pilot projects, which aimed to accelerate the diffusion of electric transport and related business in Finland, New skills and capabilities were created as a result of the interaction and collaboration between the relevant partners by combining the expertise of several different companies. One example of this kind of creative learning process was the design and deployment of a public EV charging system and related services, as well as the creation of business lines for charging services [45].

Engagement with new, low-carbon concepts can also serve to reshape roles, which is likely to be necessary for a broader shift toward a low-carbon society. For example, consumers might need to become prosumers, and new ways of funding renewable energy investments might need to be found (as highlighted, for example, by our EV crowdfunding case). However, the need to reshape roles might also be more fine-grained.

One of the problematic role divisions observed in our cases was the division of labour between different municipal administrations, which makes it difficult to integrate energy and climate issues into decision-making at all levels. The development of the Porvoo Skaftkärr low-carbon district serves as a good example of such reshaping of roles initiated by local experimentation. In Skaftkärr, the planning of the low-carbon district served to initiate a new model of concurrent town planning, where different administrations and utilities worked side by side from the start. Moreover, in this case, the pilot also led to the integration of energy and climate concerns into building permitting and land allocation policy. In this way, a large part of the municipal administration found their professional roles fundamentally transformed.

Building new networks can be an important learning outcome of smart energy pilots, which can also allow players which would not usually collaborate to find mutual interests in new collaborations. For example, in Smart Kalasatama case, the project coordinator experimented with a so-called "Innovators' Club", which adjourns four times a year to plan, follow and discuss the developments in the smart city district. The Innovators' Club brings together actors that otherwise might not come together such as start-ups, incumbent companies, developers, city representatives, smart technology providers, researchers and residents, that can also be user innovators and initiators of new service concepts. These new constellations of networks are actively co-operating and even occasionally changing the rules of the market and its balance. They are also expected to spread learning within their networks.

Inspiration and trailblazing is a type of learning that is present- to a greater or lesser extent-in all of the pilot projects. Municipal pilots served to disrupt existing modes of urban planning and development, attract forerunner companies to the pilot sites, and in general to generate pride and confidence in the capabilities of the city or town. New organization and business models served to influence development lines within companies and civil society, and to provide credibility to new solutions. Demonstration buildings are physical embodiments of combinations of new technologies-such as the Viikki Environment House, which serves as an exemplar for nearly zero-energy public buildings within Helsinki and beyond. However, serving as an example and 
inspiration requires a certain way of presenting and talking about pilot projects, where successful outcomes often overshadow the efforts and difficulties in reaching them.

\subsection{Sharing and Transfer of Lessons Learned}

Sharing of lessons learned is critical for speeding up the process of societal knowledge development [9]. It would take very long time for society to learn about low-carbon technologies if everyone needed to "reinvent the wheel". Among the fifteen case studies analysed, we found a large diversity in the ways in which lessons were shared. One of the natural division lines is that between experimentation by local governments (public projects aimed for learning in the public domain) and individual buildings (private projects aimed to support in-house learning which is not so frequently shared) [4].

Most of the literature on transfer of lessons has focused on formal and professional transfer of techno-scientific knowledge [9]. However, our case studies revealed that the notion of situated learning can also be extended to forms of lesson-sharing that are more informal and situated than formal evaluations. Informal ways of sharing lessons draw on natural processes of knowledge spillover, where people move about and discuss their experiences [30]. In our cases, lessons were often rendered mobile though such personal, face-to-face means: ambassadors, study visits, demonstrations, meetings and mobility of people between jobs. Table 4 indicates the prevalence of various forms of knowledge transfer found in the cases.

Table 4. Forms of sharing and transfer of lessons observed in the cases.

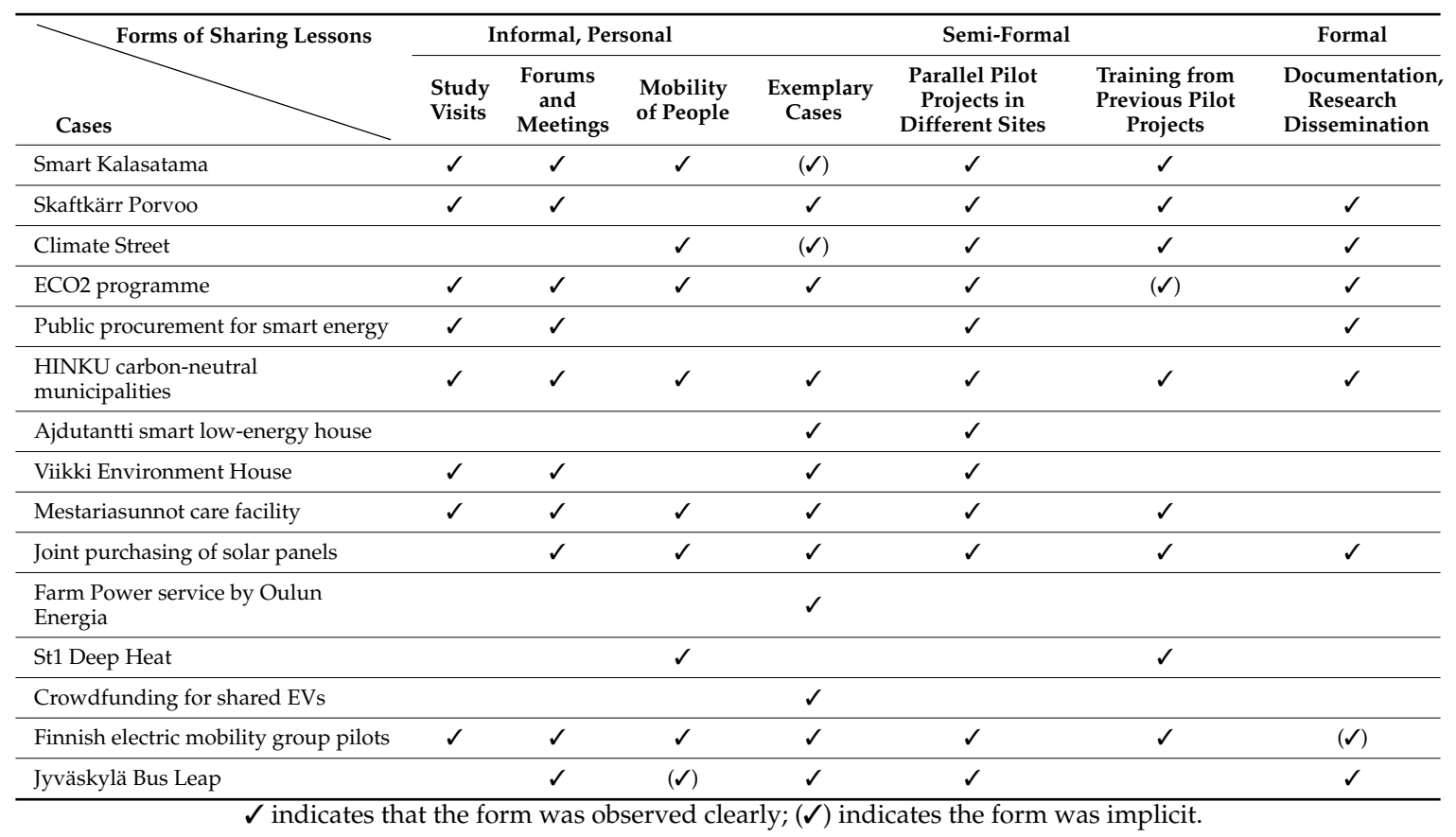

HINKU is one of the projects that has involved intensive informal lessons-sharing [46], partly due to the diverse and bottom-up nature of the project itself. Since the aim is to reduce greenhouse gas emissions, most of the formal evaluation (conducted by the project coordinator, the Finnish Environment Institute) has focused on greenhouse gas emission reductions, which has been quite significant [47]. In HINKU, knowledge transfer was originally rather piecemeal, with Finnish Environment Institute representatives transmitting best practice by travelling from one municipality to another to convene diverse locals (civil servants, residents, local businesses). Later, a HINKU Forum was established, where municipal civil servants and other local activists meet regularly to exchange experiences. Additionally, a scheme called the "HINKU deed of the month" was established, where 
best practices were awarded and showcased in order to facilitate the transfer of ideas. Forum events organized for participants, study visits, face-to-face meetings and site visits by the coordinators have been important forms of disseminating and sharing lessons among the participating municipalities, as have been the website, media coverage and regular awarding of best practices.

Dissemination of exemplary cases refers to the development of iconic cases and intensive media publicity for the successes encountered. This type of dissemination is not necessarily based on formal evaluation, though some level of documentation and e.g., calculation of achievements is necessary to make an impression in public. Among our examples, the Skaftkärr case, where the small city of Porvoo employed state-of-the art planning tools to plan a low-carbon new residential area was identified as one of these iconic cases. Some commentators argued that it was not particularly outstanding in terms of technical content (compared to some similar efforts by larger cities). However, other cities have been encouraged to apply these planning principles due to the cost savings in urban infrastructure that it renders. Our interviewees reported that politicians and planning authorities for several Finnish municipalities have visited Skaftkärr. Representatives of Sitra and the City of Porvoo have presented the project results at events for municipal decision-makers, and the project has been presented at international conferences as a local success story. According to Vehviläinen et al. [13], the results of the Skaftkärr project have been used and further developed, in several other towns in Finland and have gained widespread attention elsewhere.

We also identified another semi-formal form of lesson-sharing by running trials in parallel in different sites and training by participants from previous pilots. The Mestariasunnot nZEB elderly care building, constructed by a local social housing company, was built in parallel with another similar building (student housing Kuopas constructed by the City of Kuopio). Together, these two building developers obtained expert support from a research institute, VTT, and from qualified suppliers, e.g., in building automation. Finances for covering the extra 15\% needed for the zero-energy development were gained from three public funding bodies: Tekes, Sitra and ARA, the Housing Finance and Development Centre of Finland. Furthermore, some lessons were carried over from previous similar development projects, for example, the maintenance staff from an older building demonstration site came to train the staff of this building [48]. The practice of running parallel pilot projects in different sites was also common in those of our cases that were (often only partly) part of a European research or demonstration project, where similar measures were taken in several European cities or towns.

Not all cases were well documented or widely disseminated in a formal sense. However, for example, one of the small experiments leading up to Bus Leap was evaluated along with several other trials in Jyväskylä in a research report [49], which focused on environmental, social and economic effects and the potential for scaling up, and one part of the trial has been extensively analysed in a dissertation [50]. Some of the other urban/regional pilots have also been studied extensively, such as HINKU [41,51-54], and others are the subject of ongoing research. The large variety is naturally also based on the nature of the cases: pilot business models are not as widely covered as large municipal projects.

\subsection{Learning from Challenges: Identification of Missing Competences}

A critical question for societal knowledge development is whether we learn from the challenges encountered in local experimentation [11]. Our case studies delved into the challenges encountered when conducting the pilot projects, and sought to identify the kinds of missing competences that were identified in the course of the pilot project. This was something that few of the pilot projects had systematically communicated during the course of the pilot project or in its documentation or evaluation. However, such observations might be important, if we view the pilot projects as representing "critical niches" [55], where the problems encountered serve to reveal ways in which current competences and institutions are misaligned to the needs of a low-carbon society.

Table 5 shows the main categories and the prevalence of missing competences brought to light by our case studies. These were competence gaps experienced as barrier to the implementation or scaling 
up of the pilot (at least initially), or issues where special efforts had been made to find or develop these competences. For example, we have identified the competence as missing if external experts from national research institutes were needed for a purpose in which they do not usually participate (e.g., assessment of heating systems for a building or residential area).

Evaluation of low-carbon technologies was often a problem, due to the lack of standardized criteria, for example for comparing low-carbon decentralized heating and power production solutions with existing centralized ones. However, problems of evaluation could be even more complex, when decision makers need to compare prospective low-carbon solutions with each other and make judgments on which system will be the future "winner".

This was highlighted in the case of Public Procurement for Smart Energy, in which the City of Lappeenranta attempts to develop a smart energy ecosystem by aligning its public procurement efforts to create sufficient demand for a new, renewable, decentralized local energy system. A particular problem in this case has been the choice between gas and electric vehicles. If all of the around 200 vehicles owned by the city were converted to gas, this would allow for the development of a local combination of power-to-gas (electrolysis station) and a biogas plant. However, there are concerns that electric vehicles might be the standard solution of the future, and thus concerns that an investment in gas vehicles might be an investment in an obsolete technology. This example shows that issues of evaluation can be quite complex.

Combination of low-carbon technologies in the built environment: Several of the cases focus on combining diverse technologies (e.g., solar thermal systems, solar power, and heat pumps) and integrating them in the built environment. This can be supported by urban planning, but is strongly influenced by building design and ultimately, the installation and operation of building systems. This was one of the most critical areas where missing competences were identified: even though designers have ambitious ideas, these are often undermined by poor installation.

In the Tampere ECO2 project, several such problems were identified in an evaluation of a number of nearly zero-energy buildings (nZEBs) designed for a housing fair as part of the project. These were highly ambitious designs, but builders and installers paid very little attention to making sure systems operated as planned [56]. In an extreme case, one of the ground-source heat pumps was not turned on for a year.

Usability and system interfaces are a particular challenge for energy monitoring and control systems (i.e., building automation), which are critical for demand response, i.e., the adjustment of energy consumption according to the production of intermittent energy sources like wind and solar. There are several technologies available for this, but in several of our cases, problems were identified in the usability and system interfaces of such systems.

Particular attention has been paid to open system interfaces in the Smart Kalasatama project, which aims to develop systems that are applicable in both new and retrofitted buildings. Moreover, the aim has been to open up energy consumption data for a variety of start-ups and even user groups to develop their own applications. This is still somewhat problematic since the smart automation installed is based on wired systems (which could be prohibitively expensive to retrofit) and data are proprietary to the energy company and users. Hence, the creation of convenient ways for users to share their energy data is a key development task in the project. Since open digital interfaces for the built environment are a topical R\&D subject in Finland, real-world struggles to create open energy data can offer valuable information for scaling up digital solutions.

Integration of new practices in mainstream business is an important aim of organizing pilots and field trials of ambitious low-carbon solutions. However, as long as new solutions are more expensive and require more care in deployment than existing ones, mainstream players like construction companies are not keen to invest in them, particularly if they cannot shift the price of the new solutions to consumers when selling apartments. Customers, on the other hand, place a priority on location. 
Table 5. Missing competences identified in the cases.

\begin{tabular}{|c|c|c|c|c|c|c|}
\hline $\begin{array}{ll}\text { Type of Competence } \\
\text { Cases }\end{array}$ & $\begin{array}{l}\text { Evaluation of } \\
\text { Low-Carbon } \\
\text { Technologies }\end{array}$ & $\begin{array}{c}\text { Integrating Low-Carbon } \\
\text { Technologies in Built } \\
\text { Environment }\end{array}$ & $\begin{array}{l}\text { Usability and System } \\
\text { Interfaces }\end{array}$ & $\begin{array}{c}\text { Integrating New } \\
\text { Practices in } \\
\text { Mainstream Business }\end{array}$ & $\begin{array}{l}\text { Integrating New } \\
\text { Practices in Public } \\
\text { Administration }\end{array}$ & $\begin{array}{c}\text { Communications, Marketing } \\
\text { and Service Design }\end{array}$ \\
\hline Smart Kalasatama & & & $d$ & $\checkmark$ & 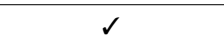 & \\
\hline Skaftkärr Porvoo & $d$ & $\checkmark$ & 1 & 1 & 1 & 4 \\
\hline $\begin{array}{l}\text { Climate Street } \\
\text { Cot }\end{array}$ & & 1 & & 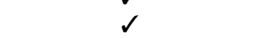 & 1 & 2 \\
\hline ECO2 programme & $\checkmark$ & 1 & 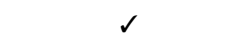 & 1 & 2 & 1 \\
\hline Smart energy via public procument & 8 & 1 & & & 1 & \\
\hline HINKU carbon-neutral municipalities & 2 & 1 & & & 1 & $d$ \\
\hline Ajdutantti smart low-energy house & & 1 & 1 & & & 1 \\
\hline Viikki Environment House & & $\checkmark$ & & $\checkmark$ & $\checkmark$ & \\
\hline Mestariasunnot care facility & $\checkmark$ & 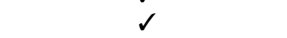 & & & & \\
\hline Joint purchasing of solar panels & & & & $\checkmark$ & $d$ & $\checkmark$ \\
\hline Farm Power service by Oulun Energia & & & & & & $\checkmark$ \\
\hline $\begin{array}{l}\text { St1 Deep Heat }\end{array}$ & & $\checkmark$ & & & $\checkmark$ & 1 \\
\hline Crowdfunding for shared EVs & & & & & $s$ & $\checkmark$ \\
\hline Finnish electric mobility group pilots & & & & 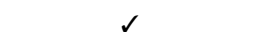 & 4 & 4 \\
\hline Jyväskylä Bus Leap & & & $\checkmark$ & & 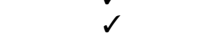 & 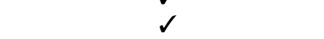 \\
\hline
\end{tabular}


Three of our cases (Smart Kalasatama, ECO2 Tampere and Skaftkärr) include examples where municipal officials have been somewhat frustrated by the difficulty of mainstreaming beyond-compliance low-energy and renewable energy applications in buildings, despite innovative urban planning and the availability of exemplary demonstration buildings. This observation suggests that at some point, attention needs to shift from demonstrating solutions to aligning market players' incentives to adopt those solutions across the board.

Integration of new practices in public administration is highlighted as a challenge in several cases. The deployment of new technologies requires new competences in planning, permitting and collaboration between different branches of the public administration. For example, projects could be severely delayed by permitting processes where standard procedures are missing or fall between administrative silos. Often, when combining technologies, several administrations need to collaborate, which also requires new procedures. In general, the support of novelties requires new more flexible ways of working and thinking within public administration, since there are no established ways of dealing with innovation and experimentation within local administrative bodies. Lessons learning in pilots and experiments can contribute, for example, to administrative reforms, such as Finland's efforts to develop more flexible regulation.

We found several cases where civil servants lacked established procedures to deal with new technology. One example is a pilot by St1 Deep Heat to bore a 7-km-deep geothermal well in the middle of a university campus, enabling the provision of $10 \%$ of the local district heat demand [57]. Since there were no precedents in Finland, there were no established permitting procedures for such projects. Similarly, installation of battery storage in the Viikki Environment House was delayed due to lack of fire safety standards for large batteries inside buildings.

Communications, marketing and service design required particular efforts in several cases. They could pertain to engaging the public in the pilot, finding out about user needs, or packaging low-carbon technologies into easily understandable and usable services.

We highlight here the case where other competences, such as evaluation of technologies, were present, but this particular competence was relatively scarce. The Farm Power service launched by Oulun Energia [58], an energy company in northern Finland, is an example of a new practice that attempts to support distributed, small-scale electricity production by allowing customers to purchase electricity from a particular provider (often a farm, using small-scale hydropower or micro-combined heat and power production). In this case study, most of the technical issues were already solved by the time the pilot study started, and the issue was to create a marketplace for locally produced, small-scale renewable energy. While the electricity contracts offered by Oulun Energia are actually relatively cost-effective for e.g., apartment building dwellers (since there is no basic charge, but only a charge per kilowatt hour consumed), the marketing and communication of the concept has not been as successful as expected. The case thus highlights a particular area in need of development. In a low-carbon and more distributed energy system, energy companies are likely to turn more into service providers, and hence their traditional technical competence needs to be complemented with additional competence in marketing, customer care and service design.

\section{Discussion and Conclusions}

Our findings highlight that several kinds of learning, both cognitive and situated, occur in Finnish low-carbon technology field trials. We found that aggregation of lessons learned in local experiments, which Geels and Deuten [7] and Raven et al. [9] deem necessary in order to support the emerging low-carbon technology trajectories, was rather limited and in most cases only pertained to particular aspects (such as cost-effectiveness and carbon dioxide reductions). Cross-case aggregation of lessons concerning other aspects deemed important in strategic experimentation such as issues of user and market acceptance, adaptability to regulations and existing infrastructures, relevant supply chains and societal impacts [1] occurred on an ad hoc basis. 
However, if we only focus on formal aggregation of lessons, our conclusions concerning learning from local experimentation in Finland would be too pessimistic. We did find vibrant development of participant capabilities through learning by doing, interacting and using [4,25]. This kind of situated learning also includes and feeds into the development of embodied competence, commitment, confidence and new identities [4].

The paucity of systematic transfer and aggregation of lessons learned through cross-case evaluations might suggest that lessons are not shared or collected. Yet, our cases show that there is significant informal and embodied sharing of lessons at study visits, events, meetings and through the mobility of people. We also found some innovative ways in which developers shared lessons and external expertise on an ongoing basis by running similar pilots in parallel. This is a good practice that could be more systematically utilized. The HINKU forum meetings serve a similar function, where participating municipalities meet to share best practices and discuss successes and problems, and they have also provided inspiration for other networks, such as a network of Finland's largest cities. Indeed, formal evaluation cannot replace the tacit knowledge and inspiration shared in face-to-face meetings and collaboration among ongoing projects-rather, it should complement it.

While these positive roles of experimentation are important, we would still argue that there is scope for more systematic sharing and aggregation of lessons learned. The speed at which such lessons diffuse can have significant impacts of how rapidly the costs of deployment of new technologies decline [13]. We did not really find systematic formats or schemes for aggregating lessons concerning problems and missing competences, which some of the national authorities attending our workshop felt was a distinct gap in the national "culture of experimentation" [4].

Yet we also observed that there are potential tensions between cognitive and situated types of learning. From the perspective of societal knowledge development, it can be highly illuminating to learn "what does not work", yet such observations are likely to undermine commitment, confidence and the development of positive identities. Our examples of situated learning showed that local experimentation is not only about the creation of new knowledge, it is also performative and political through its creation of practical skills, participant identities, new roles, communities of practice and positive narratives about the possibility of a transition toward a low-carbon society.

Given these conditions, evaluation of local sustainability experiments needs to be done with care and sensitivity. On the one hand, local experimentation for low-carbon solutions requires evaluation, if the results are to contribute to societal knowledge development. Yet "what works when and where" might not be the main question local sustainability experiments aim to address. Other questions, like distributed learning, inspiration and development of commitment and confidence might be equally valuable. Experimentation also serves to disrupt established ways of doing things and inspire companies and other actors to pursue innovative solutions.

Our observations are based on an analysis of current pilot studies in one country-a country which is particularly enthusiastic about new technology and has recently officially introduced "a culture of experimentation". This might initially give rise to a more enthusiastic but fragmented experimentation scene than in countries where experimentation has a clearer profile in policy development [24]. Moreover, our close analysis pertains to only 15 of the 100 cases, so a quantitative study of the prevalence of different types of learning, transfer of lessons, and challenges encountered still remains to be made.

However, our study provides and illustrates an analytical framework for further research on learning from pilot studies and field trials. It remains a task for further research to discover whether learning from pilot studies and field experimentation has a different profile in other countries, at other times and in other contexts than energy-related low-carbon solutions. In particular, the role of situated, local learning deserves more attention in other country contexts [59]. Moreover, we hope to challenge and inspire further research aiming to better understand and perhaps ultimately manage the tensions between cognitive and situated learning. 
Acknowledgments: The Smart Energy Transition project (SET, GA 293405) thanks the Strategic Research Council in collaboration with the Academy of Finland for their continuing support for the project.

Author Contributions: Pilots were identified by all authors collectively. The first author has written a first draft of the paper, and other authors have contributed with examples and insights from the cases they have studied. All authors have reviewed and commented on the final version.

Conflicts of Interest: The authors declare no conflict of interest. The founding sponsors had no role in the design of the study; in the collection, analyses, or interpretation of data; in the writing of the manuscript, and in the decision to publish the results.

\section{Appendix A}

Table A1. Cases in the Database of 100 Finnish Low-Carbon Technology Trials.

\begin{tabular}{|c|c|c|c|c|}
\hline $\begin{array}{l}\text { Local Government } \\
\text { Experimentation }\end{array}$ & $\begin{array}{l}\text { Pilot Studies in the } \\
\text { Built Environment }\end{array}$ & $\begin{array}{c}\text { Mobility Pilot Studies and } \\
\text { Field Trials }\end{array}$ & $\begin{array}{l}\text { New Purchasing and } \\
\text { Business Models }\end{array}$ & $\begin{array}{c}\text { Pilot Studies by } \\
\text { Traditional Companies }\end{array}$ \\
\hline Smart Kalasatama & Kempele Eco-village & eBUS and Linkker & Energy Radar of Sitra & Sundom Smart Grid \\
\hline $\begin{array}{l}\text { Porvoo Skaftskärr } \\
\text { low-carbon district }\end{array}$ & $\begin{array}{l}\text { St1's geothermal heating } \\
\text { project }\end{array}$ & HSL electric bus & $\begin{array}{l}\text { Crowdfunding of EVs } \\
\text { and renewable energy }\end{array}$ & $\begin{array}{c}\text { Fingrid, Helen and } \\
\text { There: demand response }\end{array}$ \\
\hline $\begin{array}{l}\text { HINKU carbon-neutral } \\
\text { municipalities }\end{array}$ & $\begin{array}{c}\text { Järvenpää } \\
\text { Mestaritorppa nZEB }\end{array}$ & $\begin{array}{l}\text { Electric transport trials in } \\
\text { Tampere }\end{array}$ & $\begin{array}{l}\text { Solar panel joint } \\
\text { purchasing }\end{array}$ & Fortum: INTESEM \\
\hline $\begin{array}{l}\text { Jyväskylä, resource } \\
\text { smart experiments }\end{array}$ & Kuopio Kuopas nZEB & Turku and Föli electric bus & $\begin{array}{c}\text { Snowball } \\
\text { crowdsourcing }\end{array}$ & Ruukki: Solar Roof \\
\hline $\begin{array}{l}\text { Turku Skanssi open } \\
\text { district heat network }\end{array}$ & $\begin{array}{l}\text { Viikki environmental } \\
\text { house }\end{array}$ & $\begin{array}{l}\text { Sustainable transport in Turku } \\
\text { (biogas) }\end{array}$ & $\begin{array}{l}\text { Senaatti real estate } \\
\text { competitive bidding for } \\
\text { renewable energy }\end{array}$ & $\begin{array}{l}\text { Woikoski: hydrogen } \\
\text { filling station }\end{array}$ \\
\hline $\begin{array}{l}\text { Jyväskylä Kangas, } \\
\text { Kytkin project }\end{array}$ & $\begin{array}{l}\text { Adjutantti smart solar } \\
\text { apartment building }\end{array}$ & $\begin{array}{l}\text { Optibio-biofuels in Helsinki } \\
\text { buses }\end{array}$ & VTT SmartCityKey & $\begin{array}{l}\text { Oulu Energy: } \\
\text { "Farmivirta" }\end{array}$ \\
\hline $\begin{array}{l}\text { Lappeenranta Green } \\
\text { Campus }\end{array}$ & Wasa Station & MaaS Finland & $\begin{array}{l}\text { BioSampo Training and } \\
\text { Research Centre }\end{array}$ & $\begin{array}{l}\text { Demand response for } \\
\text { district heat (Fortnum } \\
\text { and Leanheat) }\end{array}$ \\
\hline $\begin{array}{l}\text { Forssa industrial } \\
\text { symbiosis }\end{array}$ & Vaasa Suvilahti & $\begin{array}{l}\text { Hämeenlinna MaaS/growth } \\
\text { area }\end{array}$ & $\begin{array}{l}\text { Helen, Energy } \\
\text { Hackatholon }\end{array}$ & $\begin{array}{l}\text { Virpa: (S Group demand } \\
\text { response) }\end{array}$ \\
\hline $\begin{array}{l}\text { Tampere Co-ZED } \\
\text { Härmälänranta }\end{array}$ & $\begin{array}{l}\text { Helen Sakarinmäki } \\
\text { School }\end{array}$ & MaaS trial Imatra & $\begin{array}{l}\text { PLEEC local energy } \\
\text { planning }\end{array}$ & $\begin{array}{l}\text { Fortum: Charge and } \\
\text { Drive }\end{array}$ \\
\hline Espoo Finnoo & Pilots for solar business & MaaS trial Seinäjoki & $\begin{array}{l}\text { Lappeenranta solar } \\
\text { town plan }\end{array}$ & Gasum: Biogas \\
\hline Tampere Vuores & $\begin{array}{l}\text { SenCity smart lighting } \\
\text { pilot network }\end{array}$ & MaaS trial Ylläs & $\begin{array}{l}\text { Competitive bidding for } \\
\text { offshore wind }\end{array}$ & $\begin{array}{l}\text { Granlund rapid } \\
\text { experimentation }\end{array}$ \\
\hline Eco-suburb & $\begin{array}{l}\text { Tampere Hämeenpuisto } \\
\qquad 21\end{array}$ & Transport laboratory & $\begin{array}{l}\text { Sykli, EENavi energy } \\
\text { renovation training }\end{array}$ & $\begin{array}{l}\text { Helen: Suvilahti solar } \\
\text { power station and } \\
\text { battery }\end{array}$ \\
\hline Riihimäki Peltosaari & House 2020 & EVE projects & $\begin{array}{l}\text { Public procurement for } \\
\text { smart energy, } \\
\text { Lappeenranta }\end{array}$ & Fortum: Home Display \\
\hline $\begin{array}{l}\text { Pitkäniemi heat pump } \\
\text { system }\end{array}$ & $\mathrm{ABC}$, Citymarket & $\begin{array}{l}\text { Liikennevirta, EV charging } \\
\text { stations }\end{array}$ & $\begin{array}{l}\text { Tampere, Vuores PV } \\
\text { purchasing }\end{array}$ & $\begin{array}{l}\text { Helen: indirect load } \\
\text { control }\end{array}$ \\
\hline $\begin{array}{c}\text { Kolmenkulma } \\
\text { Eco-Industrial Park }\end{array}$ & AthLEDics project & $\begin{array}{l}\text { Support for electric vehicles } \\
\text { (TEM) }\end{array}$ & $\begin{array}{l}\text { Jyväskylä, LED } \\
\text { purchasing }\end{array}$ & $\begin{array}{l}\text { Lappeenranta Energy } \\
\text { local energy service }\end{array}$ \\
\hline $\begin{array}{l}\text { RESCA Oulu pilot area } \\
\text { for renewable energy }\end{array}$ & $\begin{array}{l}\text { Solar power in housing } \\
\text { co-operatives }\end{array}$ & Experimental Finland & $\begin{array}{l}\text { Salo LED lighting as a } \\
\text { service }\end{array}$ & Wärtsilä: fuel cells \\
\hline $\begin{array}{l}\text { Östersundom Smart and } \\
\text { Clean, Helsinki }\end{array}$ & BuildUp Skills & Autonomous vehicle trials & $\begin{array}{c}\text { nZEB-project } \\
\text { capabilities, Tampere }\end{array}$ & Oulu energy: solar pilot \\
\hline $\begin{array}{l}\text { Sybimar industrial } \\
\text { symbiosis }\end{array}$ & Villa Isover Hyvinkää & EkoRent & & $\begin{array}{l}\text { Jyväskylä Energy } \\
\text { low-carbon house }\end{array}$ \\
\hline $\begin{array}{l}\text { Oulu Hiukkavaara } \\
\text { Arctic Smart City }\end{array}$ & $\begin{array}{l}\text { Teemu Varpainen, smart } \\
\text { solar house }\end{array}$ & Green Riders & & $\begin{array}{c}\text { Lammais energy: SUN } \\
\text { solar service }\end{array}$ \\
\hline \multirow[t]{2}{*}{$\begin{array}{l}\text { Mikkeli Satamalahti } \\
\text { digital city }\end{array}$} & $\begin{array}{l}\text { YIT Elderly home } \\
\text { Onnelanpolku }\end{array}$ & $\begin{array}{l}\text { Joint transport system } \\
\text { Helsinki-Tallinn }\end{array}$ & & $\begin{array}{l}\text { Fortum/Helen: solar } \\
\text { packages }\end{array}$ \\
\hline & $\begin{array}{l}\text { Lappeenranta Green } \\
\text { Campus }\end{array}$ & PiggyBaggy distribution service & & \\
\hline & & HSL environmental bonus & & \\
\hline
\end{tabular}


Appendix B : Case Reports Presenting Detailed Empirical Research Results and More Detailed References for Each Case (All Reports, Apart from 15, in Finnish) Used as Material for the Present Article. All Drafts Will Be Published in the Aalto University Working Papers Series by September 2017

1. Matschoss, K.; Korhonen, K. WP4 Case: Fiksu Kalasatama (Smart Kalasatama). Aalto University Working Papers. 2016, CROSSOVER 13/2016.

2. Heiskanen, E. WP4 Case: Porvoon Skaftkärr (Skaftkärr, Porvoo) Aalto University Working Papers. 2017, CROSSOVER 5/2017.

3. Korhonen, K.; Matschoss, K. WP4 Case: Helsingin Ilmastokatu (Climate Street), in press.

4. Heiskanen, E. Tampereen ECO2 ja kestävän yhdyskunnan pilotit (Tampere ECO2 programme and sustainable community pilots), in press.

5. Heiskanen, E. Lappeenrannan kaupunki uusien energiaratkaisujen edistäjänä (Public procurement for smart energy, Lappeenranta). Draft.

6. Heiskanen, E.; Jalas, M.; Rinkinen, J.; Tainio, P. The local community as a "low-carbon lab": Promises and perils. Environ. Innov. Soc. Transit. 2015, 14, 149-164. (reference for HINKU Carbon Neutral municipalities case)

7. Huomo, T. WP4 Case: Mäkkylän Adjutanttitalo Espoossa (Adjutantti Smart Low-Energy House) Aalto University Working Papers. 2016, CROSSOVER 9/2016.

8. Korhonen, K. Viikin ympäristötalo ja sähkövarasto (Viikki Environmental House), in press.

9. Heiskanen, E.; Nissilä, H.; Lovio, R. Demonstration buildings as protected spaces for clean energy solutions-the case of solar building integration in Finland. J. Clean. Prod. 2015, 109, 347-356. (reference for Mestariasunnot care facility case)

10. Seppälä, A. WP4 Case: Välke-hankeen aurinkosähköjärjestelmien yhteishankinta (Joint purchasing of solar panels), in press.

11. Kallio, L. WP4 Case: Oulun Energian Farmivirta-palvelu (Farm Power service by Oulun Energia). Aalto University Working Papers. 2017, CROSSOVER 1/2017.

12. Norberg, J.; Rask, M. WP4 Case St1 Deep Heat, in press.

13. Erkkilä, H.-K. WP4 Case: Joukon Voiman ja Ekorentin joukkorahoituskampanja (Crowdfunding for shared EVs). Aalto University Working Papers. 2016, CROSSOVER 12/2016.

14. Hyvönen, K. Pääkaupunkiseudun sähköisen liikenteen kokeilut (Finnish electric mobility group pilots). Draft.

15. Laakso, S. Bussiloikka, Jyväskylä (Jyväskylä Bus Leap), in press.

\section{References}

1. Schot, J.; Geels, F.W. Strategic niche management and sustainable innovation journeys: Theory, findings, research agenda, and policy. Technol. Anal. Strateg. Manag. 2008, 20, 537-554. [CrossRef]

2. Bossink, B.A. Demonstration projects for diffusion of clean technological innovation: A review. Clean Technol. Environ. Policy 2015, 17, 1409-1427. [CrossRef]

3. Heiskanen, E.; Jalas, M.; Rinkinen, J.; Tainio, P. The local community as a "low-carbon lab": Promises and perils. Environ. Innov. Soc. Trans. 2015, 14, 149-164. [CrossRef]

4. Fevolden, A.M.; Coenen, L.; Hansen, T.; Klitkou, A. The Role of Trials and Demonstration Projects in the Development of a Sustainable Bioeconomy. Sustainability 2017, 9, 419. [CrossRef]

5. Ornetzeder, M.; Rohracher, H. Passive Houses in Austria: The Role of Intermediary Organizations for the Successful Transformation of a Socio-Technical System. Available online: http:/ /www.eceee.org/library / conference_proceedings/eceee_Summer_Studies/2009/Panel_7/7.175/paper (accessed on 10 May 2017).

6. Jacobsson, S.; Lauber, V. The politics and policy of energy system transformation-Explaining the German diffusion of renewable energy technology. Energy Policy 2006, 34, 256-276. [CrossRef]

7. Dewald, U.; Truffer, B. The local sources of market formation: Explaining regional growth differentials in German photovoltaic markets. Eur. Plan. Stud. 2012, 20, 397-420. [CrossRef] 
8. Berg, A.; Hildén, M.; Lahti, K. Kohti Kokeilukulttuuria: Analyysi Jyväskylän Resurssiviisaista Kokeiluista Strategisen Kehittämisen Työkaluina (Toward an Experimental Culture: Analysis of Resource-Wise Experiments in Jyväskylä as Tools for Strategic Development). Available online: https://media.sitra. fi/2017/02/24015320/Selvityksia77.pdf (accessed on 10 May 2017).

9. Raven, R.P.; Heiskanen, E.; Lovio, R.; Hodson, M.; Brohmann, B. The contribution of local experiments and negotiation processes to field-level learning in emerging (niche) technologies: Meta-analysis of $27 \mathrm{new}$ energy projects in Europe. Bull. Sci. Technol. Soc. 2008, 28, 464-477. [CrossRef]

10. Sabel, C.F.; Zeitlin, J. Learning from difference: The new architecture of experimentalist governance in the EU. Eur. Law J. 2008, 14, 271-327. [CrossRef]

11. Kivimaa, P.; Hildén, M.; Huitema, D.; Jordan, A.; Newig, J. Experiments in Climate Governance-A Systematic Review of Research on Energy and Built Environment Transitions. J. Clean. Prod. 2017. Available online: http:/ /dx.doi.org/10.1016/j.jclepro.2017.01.027 (accessed on 10 May 2017). [CrossRef]

12. Finnish Government. Finland, a Land of Solutions. Available online: http://valtioneuvosto.fi/documents / 10184/1427398/Ratkaisujen+Suomi_EN_YHDISTETTY_netti.pdf/8d2e1a66-e24a-4073-8303-ee3127fbfcac (accessed on 10 May 2017).

13. Sørensen, K. Beyond innovation. Towards an extended framework for analysing technology policy. Nord. J. Sci. Technol. 2013, 1, 12-23. [CrossRef]

14. Neij, L.; Heiskanen, E.; Strupeit, L. The deployment of new energy technologies and the need for local learning. Energy Policy 2017, 101, 274-283. [CrossRef]

15. Rose, R. What is lesson-drawing? J. Public Policy. 1991, 11, 3-30. [CrossRef]

16. Lovell, $\mathrm{H}$. The role of individuals in policy change: The case of UK low-energy housing. Environ. Plan. $C$ Gov. Policy. 2009, 27, 491-511. [CrossRef]

17. Chini, C.M.; Canning, J.F.; Schreiber, K.L.; Peschel, J.M.; Stillwell, A.S. The Green Experiment: Cities, Green Stormwater Infrastructure, and Sustainability. Sustainability 2017, 9, 105. [CrossRef]

18. Geels, F.; Deuten, J.J. Local and global dynamics in technological development: A socio-cognitive perspective on knowledge flows and lessons from reinforced concrete. Sci. Public Policy 2006, 33, 265-275. [CrossRef]

19. Sengers, F.; Wieczorek, A.J.; Raven, R. Experimenting for sustainability transitions: A systematic literature review. Technol. Forecast. Soc. Chang. 2016, in press. [CrossRef]

20. Luederitz, C.; Schäpke, N.; Wiek, A.; Lang, D.J.; Bergmann, M.; Bos, J.J.; Burch, S.; Davies, A.; Evans, J.; König, A.; et al. Learning through evaluation-A tentative evaluative scheme for sustainability transition experiments. J. Clean. Prod. 2016, in press. [CrossRef]

21. McFadgen, B.; Huitema, D. Are All Experiments Created Equal? A Framework for Analysis of the Learning Potential of Policy Experiments in Environmental Governance. Available online: http:/ /dx.doi.org/10.1080/ 09640568.2016.1256808 (accessed on 10 May 2017).

22. Wolfram, M.; Frantzeskaki, N. Cities and systemic change for sustainability: Prevailing epistemologies and an emerging research agenda. Sustainability 2016, 8, 144. [CrossRef]

23. Moloney, S.; Horne, R. Low carbon urban transitioning: from local experimentation to urban transformation? Sustainability 2015, 7, 2437-2453. [CrossRef]

24. Lammers, I.; Diestelmeier, L. Experimenting with Law and Governance for Decentralized Electricity Systems: Adjusting Regulation to Reality? Sustainability 2017, 9, 212. [CrossRef]

25. Jensen, M.B.; Johnson, B.; Lorenz, E.; Lundvall, B.Å. Forms of knowledge and modes of innovation. Res. Policy 2007, 36, 680-693. [CrossRef]

26. Lave, J.; Wenger, E. Situated Learning: Legitimate Peripheral Participation; Cambridge University Press: Cambridge, UK, 1991.

27. Handley, K.; Sturdy, A.; Fincham, R.; Clark, T. Within and beyond communities of practice: Making sense of learning through participation, identity and practice. J. Manag. Stud. 2006, 43, 641-653. [CrossRef]

28. Ibarra, H. 'Provisional selves: experimenting with image and identity in professional adaptation'. Adm. Sci Q. 1999, 44, 764-791. [CrossRef]

29. Brown, J.S.; Duguid, P. Organizational learning and communities-of-practice: Toward a unified view of working, learning, and innovation. Org. Sci. 1991, 2, 40-57. [CrossRef]

30. Asheim, B.T.; Coenen, L.; Vang, J. Face-to-face, buzz, and knowledge bases: Sociospatial implications for learning, innovation, and innovation policy. Environ. Plan. C 2007, 25, 655-670. [CrossRef]

31. Dosi, G. Sources, Procedures and Microeconomic Effects of Innovation. J. Econ. Lit. 1988, 26, 1120-1171. 
32. Polley, D.; van de Ven, A.H. Learning by discovery during innovation development. Int. J. Technol. Manag. 1996, 11, 871-882.

33. Lampel, J. Show-and-tell: Product demonstrations and path creation of technological change. In Path Dependence and Creation; Garud, R., Karnoe, P., Eds.; Lawrence Erlbaum Associates: Mahwah, NJ, USA, 2001; pp. 303-327.

34. Motiva. Selvitys Hajautetusta ja Paikallisesta Energiantuotannosta Erilaisilla Asuinalueilla. (Study of Distributed and Local Energy Production in Diverse Residential Areas). Report by Gaia Consulting for Motiva Ltd. Available online: https://www.motiva.fi/ajankohtaista/julkaisut/uusiutuva_energia/selvitys_hajautetusta_ ja_paikallisesta_energiantuotannosta_erilaisilla_asuinalueilla.10768.shtml (accessed on 25 April 2016).

35. Botero, A.; Vihavainen, S.; Karhu, K. From Closed to Open to What?: An Exploration on Community Innovation Principles. In Proceedings of the 13th International MindTrek Conference: Everyday Life in the Ubiquitous Era, Tampere, Finland, 30 September-2 October 2009.

36. Smart Kalasatama. Programme for Agile Piloting. Available online: https://fiksukalasatama.fi/en/agilepiloting/ (accessed on 10 May 2017).

37. Climate Street. Nopeat Kokeilut. Available online: http://ilmastokatu.fi/nopeat-kokeilut/ (accessed on 10 May 2017).

38. Skanska. Adjutantti, Finland. Case Study 95. Sustainability Case Study. Available online: http:/ /www.skanskasustainability-case-studies.com/index.php/latest-case-studies/item/177-adjutantti-finland (accessed on 10 May 2017).

39. Aurinkosähköhankkeet (Solar Power Projects). Available online: http://aurinkovirta.fi/aurinkosahkohankkeet/ (accessed on 10 May 2017).

40. Välimäki, P.; Kotakorpi, E.; Willman, K.; Viertola, K.; Närhi, M. ECO2-Eco-efficient Tampere 2020: First 3 Years; City of Tampere: Tampere, Finland, 2013.

41. Saikku, L.; Tainio, P.; Hildén, M.; Antikainen, R.; Leskinen, P.; Koskela, S. Diffusion of solar electricity in the network of private actors as a strategic experiment to mitigate climate change. J. Clean. Prod. 2017, 142, 2730-2740. [CrossRef]

42. Vepsäläinen, J. Energia-Alan Osaamistarpeet Tulevaisuudessa. (Future Competence Needs in the Energy Sector). Available online: http://www.oph.fi/download/179772_Alustava_luonnos_Vepsalainen_Jukka.pdf (accessed on 10 May 2017).

43. Pawson, B.R.; Tilley, N. An Introduction to Scientific Realist Evaluation. In Evaluation for the 21st Century: A Handbook; Chelimsky, E., Shadish, W.R., Eds.; Sage Publications: Thousand Oaks, CA, USA, 1997; pp. 405-418.

44. Pesola, A.; Autio, M.; Alam, J.; Ylimäki, L.; Descombes, L.; Vehviläinen, I.; Vanhanen, J. Energiatehokkaiden Malliratkaisujen Seuranta ja Asukasnäkökulma. (Monitoring and Resident Perspective on Energy Efficient Model Solutions). Asumisen Rahoitus-ja Kehittämiskeskuksen Raportteja 1/2016. Available online: http: / /www.ara.fi/fi-FI/ARAtietopankki/Julkaisut/ARAn_raportteja_julkaisusarja (accessed on 17 May 2017).

45. Antikainen, M. EVE-Electric Vehicle Systems 2011-2015. Available online: https://www.tekes.fi/ globalassets/julkaisut/eve_final_report.pdf (accessed on 10 May 2017).

46. Mickwitz, P.; Hildén, M.; Seppälä, J.; Melanen, M. Sustainability through system transformation: Lessons from Finnish efforts. J. Clean. Prod. 2011, 19, 1779-1787. [CrossRef]

47. HINKU. Towards Carbon Neutral Municipalities-An Innovative Finnish Approach. Available online: www.hinkufoorumi.fi/en-us (accessed on 10 May 2017).

48. Heiskanen, E.; Nissilä, H.; Lovio, R. Demonstration buildings as protected spaces for clean energy solutions-The case of solar building integration in Finland. J. Clean. Prod. 2015, 109, 347-356. [CrossRef]

49. Mattinen, M.; Antikainen, R.; Salo, M. Jyväskylän Resurssiviisaiden Kokeilujen Vaikutusarviointi Sekä Laajenemisvaikutukset. (Impact Assessment and Scaling Effects of the Jyväskylä Resource-Wise Experiments). Available online: https://media.sitra.fi/2014/01/21155454/Selvityksia75.pdf (accessed on 10 May 2017).

50. Laakso, S. Practice Approach to Experimental Governance. Experiences from the Intersection of Everyday Life and Experimental Culture. Academic Dissertation, University of Helsinki, Helsinki, Finland, 2017.

51. Kopsakangas-Savolainen, M.; Juutinen, A. Energy consumption and savings: A survey-based study of Finnish households. J. Environ. Econ. Policy 2013, 2, 71-92. [CrossRef] 
52. Pitkänen, K.; Antikainen, R.; Droste, N.; Loiseau, E.; Saikku, L.; Aissani, L.; Thomsen, M. What can be learned from practical cases of green economy?-Studies from five European countries. J. Clean. Prod. 2016, 139, 666-676. [CrossRef]

53. Mattinen, M.K.; Heljo, J.; Vihola, J.; Kurvinen, A.; Lehtoranta, S.; Nissinen, A. Modeling and visualization of residential sector energy consumption and greenhouse gas emissions. J. Clean. Prod. 2014, 81, 70-80. [CrossRef]

54. Matschoss, K.; Heiskanen, E. Making it experimental in several ways: The work of intermediaries in raising the ambition level in local climate initiatives. J. Clean. Prod. 2017, in press. [CrossRef]

55. Smith, A.; Hargreaves, T.; Hielscher, S.; Martiskainen, M.; Seyfang, G. Making the most of community energies: Three perspectives on grassroots innovation. Environ. Plan. A 2016, 48, 407-432. [CrossRef]

56. Kallioharju, K.; Honkiniemi, M.; Juvela, J.P.; Lipsanen, E.; Uusitalo, S. Vuoreksen Olosuhde-ja Energiaseurantahanke. Loppuraportti. (Vuores Monitoring Report on Indoor Air Quality and Energy Consumption) Tampere: Tampere Polytechnic TAMK. 2015. Available online: http://tate.blogs.tamk.fi/ vuores/vuores-hanke/vuoreksen-seurantahankkeen-julkaisuja/ (accessed on 10 May 2017).

57. ST1. St1's Geothermal Heating Project Approaching Pilot Plant Stage. Press release. 2017. Available online: http:/ / www.st1.eu/news/st1s-geothermal-heating-project-approaching-pilot-plant-stage (accessed on 10 May 2017).

58. Oulun Energia. Farm Power. Press Release. 2016. Available online: https://www.oulunenergia.fi/en/productsand-services/electricity-homes/electricity-contracts-homes/farm-power (accessed on 10 May 2017).

59. Holm, J.; Stauning, I.; Søndergård, B. Local Climate Mitigation and Eco-efforts in Housing and Construction as Transition Places. Environ. Policy Gov. 2011, 21, 183-198. [CrossRef]

(C) 2017 by the authors. Licensee MDPI, Basel, Switzerland. This article is an open access article distributed under the terms and conditions of the Creative Commons Attribution (CC BY) license (http:/ / creativecommons.org/licenses/by/4.0/). 